\title{
EDUCAÇÃO E SOCIEDADE: O ALUNO NO PROCESSO DE ENSINO E APRENDIZAGEM SEGUNDO A SOCIOLOGIA DA INFÂNCIA
}

\author{
Danieli Cristina Ferreira ${ }^{1}$, Jaqueline da Cruz $^{1}$, Nair Correia Salgado de Azevedo ${ }^{2}$ \\ ${ }^{1}$ Licenciadas em Pedagogia pela Universidade do Oeste Paulista - UNOESTE, Presidente Prudente/SP. \\ ${ }^{2}$ Doutora em Educação pela Universidade Estadual Paulista - UNESP, Presidente Prudente, SP. Professora do Curso de \\ Licenciatura em Pedagogia da Universidade do Oeste Paulista - UNOESTE, Presidente Prudente, SP.
}

\section{RESUMO}

Esse artigo se propõe a discutir o processo de formação crítica das crianças pelo contexto escolar. Para isso, realizaremos uma reflexão sobre a história da infância, a partir do século XIX, no Brasil, para entendermos a importância de ouvirmos as opiniões das crianças, tão importante para o processo de formação crítica que deve ser propiciada pela escola. Usaremos como um dos norteadores para essa reflexão, os estudos da Sociologia da Infância, área que vem, atualmente, discutindo com afinco a importância de reconhecermos o papel das crianças como sujeitos nos processos educacionais. Além disso, pretende-se também realizar uma discussão sobre a importância da mediação do professor nesse processo, partindo do pressuposto de que, o professor que buscar introduzir a formação crítica de seus alunos por meio de debates e discussões relacionadas a interesses e perspectivas das crianças, conduz, de forma mais adequada, esse processo de formação crítica.

Palavras-Chave: Educação. Sociologia da infância. Sociedade. Criança.

\section{EDUCATION AND SOCIETY: THE STUDENT IN THE PROCESS OF TEACHING AND LEARNING ACCORDING TO SOCIOLOGY OF CHILDHOOD}

\begin{abstract}
This article proposes to discuss the process of critical formation of children through the school context. For this, we will reflect on the history of childhood from the 19th century in Brazil to understand the importance of listening to the opinions of children, so important for the process of critical formation that should be provided by the school. We will use as one of the guiding principles for this reflection the studies of Sociology of Childhood, an area that is currently discussing the importance of recognizing the role of children as subjects in educational processes. In addition, it is also intended to conduct a discussion about the importance of teacher mediation in this process, based on the assumption that, the teacher who seeks to introduce the critical formation of their students through discussions and discussions related to interests and perspectives of children, Leads, more appropriately, this process of critical formation.
\end{abstract}

Keywords: Education. Sociology of childhood. Society. Child.

\section{INTRODUÇÃO}

Este trabalho pretende contribuir para as discussões sobre um dos papéis da Educação na sociedade: a promoção da visão crítica do aluno no processo de ensino aprendizagem. $O$ tema foi escolhido, por ser um assunto que precisa ser estudado e aprofundado, pois a Educação e a sociedade não estão dissociadas no processo crítico de formação do aluno. Entendemos que esse tema merece ser discutido no processo de formação inicial de professores para que no exercício da prática se tenham meios que possibilitem um melhor desempenho para atuar com os alunos.

Sabemos que a educação molda a sociedade, pois segundo Poyer (2007, p.17) "a escola é compreendida como uma das partes que compõe o processo social". A criança sempre recebe a influência de vários setores da sociedade em seu processo de formação, como 
por exemplo, o meio familiar, o meio cultural, o contexto político e o meio escolar. Abordaremos, no decorrer deste trabalho, algumas dessas relações, já que todas elas englobam o processo de socialização e cultura, tão importantes para a formação crítica dos membros da sociedade.

Fazer tais relações se torna importante, pois de acordo com Dewey (1999) o aluno vive num contexto social e se relaciona com várias pessoas e em vários contextos igualmente relevantes para o processo de construção crítica do aluno: "O aluno antes de ser aluno, é um ser humano que não vive só. É um indivíduo que convive com outros indivíduos. Portanto, a educação também é um processo social, que começa na família, se desenvolve na escola e se aplica no trabalho" (DEWEY, apud AGUIAR, 1994, p.16).

Sabemos que para o aluno ter uma boa educação e que o seu processo de aprendizagem aconteça com êxito é necessário que a sociedade, familiares, escolas e professores exerçam o seu papel com comprometimento, sem que nenhum deixe de cumprir as suas funções específicas. Em parceria, esse processo de construção crítica do conhecimento pode ser realizado de forma mais coerente.

Vemos todos os dias transformações instantâneas em nosso mundo, como por exemplo, a globalização. É por ela, por exemplo, que podemos aqui citar o processo de mercantilização e o capitalismo como alguns dos principais agentes dessas mudanças, em que se cria, em muitos momentos, o interesse em viver numa sociedade em que o "Ter" acaba sendo mais valorizado que o "Ser". Pensando ser essa a melhor forma de inserção social nesse mundo, muitos pensam e agem de forma a se inserir nessa já imposta conduta social.

Sendo assim, elegemos a escola como um ambiente propício para que tais discussões, por exemplo, possam ser realizadas com os alunos de forma a contribuir para sua formação crítica. É fundamental estimular essas discussões partindo principalmente dos conhecimentos prévios que os alunos possuem e de sua realidade social. Mas o que discutir, afinal, com os alunos para que eles tenham essa visão crítica de mundo? Como fazer com que nossos alunos se interessem por tentativas de mudança de sua realidade?

Acreditamos que, para se realizar discussões como essas nas escolas, é preciso ouvir os alunos. Dar a oportunidade para que eles falem sobre sua realidade pode ser o termômetro para que o professor, num primeiro momento, selecione os assuntos considerados mais importantes para o aluno. Partindo dessa verificação, o professor poderá, em momentos diversos de suas aulas, promover debates, discussões e tentar planejar metas e ações para que algo possa ser feito.

Dessa forma, a criança se sentirá respeitada pela escola que tenta, assim, oferecer condições para que ela possa desenvolver-se criticamente em seu processo de construção e organização da realidade possibilitando a autonomia do aluno. Cabe ao professor no processo educativo mediar os conhecimentos e habilidades, estimular as crianças e jovens a desenvolver o raciocínio e autonomia, além de ensinar a pensar sobre diferentes problemas, auxiliando no crescimento intelectual e na formação de cidadãos capazes de gerar transformações positivas na sociedade. $O$ professor não pode agir como único detentor do saber, pois ele, juntamente com seus alunos, participa como um mediador de conhecimentos e conteúdos, sendo um dos responsáveis por guiar o processo de aprendizagem (DEWEY, apud AGUIAR, 1994).

Além disso, o professor deve procurar desenvolver a autonomia do aluno para que ele venha ter independência, liberdade de pensar e expor as suas ideias. Dessa forma, o professor adota uma postura de respeito à criança e valoriza o seu pensamento, para que ela venha adquirir suas percepções próprias e desenvolver seu lado crítico.

Em alguns momentos percebemos que a educação e a sociedade não estão conseguindo se articular de forma a promover essa interação entre ambos, pois a escola, muitas vezes, tem como objetivo formar alunos com um determinado padrão de conduta exigida pela sociedade atual. Porém muitos fatores sociais como a desigualdade entre classes, o processo de inclusão, a competição para o mercado de trabalho, etc., estão influenciando no processo de educação do aluno. É importante que a escola se reconheça como um agente relevante no processo de intervenção educacional, e realize ações que levem o aluno a pensar e refletir sobre sua realidade (DEWEY, apud AGUIAR, 1994).

$O$ processo educativo seria uma das melhores formar de beneficiar a sociedade, e quanto mais eficiente for o processo no sentido de incentivar a criticidade do aluno com relação à sua realidade, melhor será o desenvolvimento da 
comunidade. A escola exerce um papel fundamental considerando a cultura e socializando o aluno.

A educação tem potencialmente uma grande capacidade de ser transformadora, tanto no sentido cultural, quanto no sentido do desenvolvimento social, e os alunos deveriam ter escolas que proporcionassem uma educação que promovesse a criticidade social.

O aluno, então, precisa de uma educação por meio da qual o professor proporcione a liberdade, levando-os a raciocinar para depois confrontar com o conhecimento sistematizado e a realidade instaurada. Sendo assim, estará contribuindo para um processo de socialização, formando cidadãos com autonomia e pensamentos próprios.

Nas últimas décadas muitas discussões estão acontecendo no sentido de mudar a visão que temos das crianças nos processos educacionais e/ou acadêmicos. Os processos de pesquisas em que os sujeitos são crianças, por exemplo, ou processos sobre a prática pedagógica, como aquela em que ocorre no contexto das salas de aula, são exemplos de tais debates (SARMENTO, 2011).

Independente da situação mencionada, o fato é que toda essa discussão de inserção da criança como um sujeito do processo precisa passar pela quebra de alguns paradigmas. De acordo com Sarmento (2011), uma das áreas que tem procurado realizar uma discussão significativa nesse sentido é a Sociologia da Infância.

Devemos nesse momento lembrar que, as crianças foram, durante muito tempo, ignoradas por muitos setores de nossa sociedade, incluindo os estudos educacionais e sociológicos, que mesmo atuando diretamente com a infância, pouco se apropriou de suas especificidades no decorrer da história e em seus estudos específicos (MÜLLER; CARVALHO, 2009).

Essa busca pela identidade infantil se dá pelo que Ferreira (2009) denomina como "novo paradigma da sociologia da infância", que sugere o abandono da criança objeto concebida por ideias tradicionais, o que implica penetrar no mundo das crianças, envolvê-las como coparticipantes e construir conhecimentos com as crianças. Para isso, é preciso reconhecer a infância como uma construção social que não pode ser compreendida separada de outras variáveis, como a de gênero, de classe social, etnia etc., além de ser reconhecida como categoria a ser estudada no presente, com as atuais configurações, e não em relação ao seu futuro como adultas.

Conforme Saramago (2001), a infância é caracterizada por um núcleo próprio, com relações intergrupais típicas, protagonizadas pelas crianças e que, por sua vez, são capazes de intervir socialmente pela própria experiência. Além disso, a autora nos alerta para o fato de que a escola pode ser eleita como um local privilegiado para a interação e observação desse grupo geracional, pois se trata de um agente muito importante em seu processo de socialização aos pares.

As relações intergrupais na qual Saramago (2001) se refere foi conceituada pelo sociólogo Willian Corsaro (2011), especialista em sociologia da infância, assim como a "cultura de pares". O termo "cultura de pares" é definido pelo autor "como um conjunto estável de atividades ou rotinas, artefatos, calores e preocupações que as crianças produzem e compartilham em interação com as demais" (CORSARO, 2011, p. 128).

Segundo Corsaro (2011), embora as crianças desempenhem um importante papel na produção de rotinas culturais com os adultos, seja na família ou em outros ambientes, as atividades ocorridas com outras crianças e sua produção coletiva - que gera, consequentemente, uma série de cultura de pares - são tão importantes como a interação delas com os adultos.

Isso, porém, não implica desconsiderar a relação das crianças com os adultos, pois serão eles que proporão desafios às crianças para que elas se desenvolvam em seu processo educativo (CORSARO, 2011).

Portanto, a Sociologia da Infância nos ajuda a refletir e mudar nossas opiniões sobre vários aspectos, entre eles o fato de considerarmos a voz das crianças. Sabemos, de acordo com estudos históricos sobre a infância, como os realizados por Ariès (1978), que durante muito tempo as crianças foram vistas como um "vir a ser"; e na história da humanidade não foram, durante séculos, sequer consideradas como membros da sociedade (tal discussão será mais aprofundada durante esse estudo, em que pretendemos fazer uma reflexão histórica sobre a infância) e é preciso discutir a atuação das crianças como seres ativos no processo de construção do conhecimento científico para a infância. 
Sarmento (2011) nos lembra de que a expressão "ouvir a voz das crianças" condensa todo um programa teórico que constata o silêncio no qual as crianças foram historicamente submetidas. A sociologia da infância então tem se preocupado em estudar as crianças como atores sociais de pleno direito, analisando-as como categoria geracional. Mas, mais que ouvir as vozes, é preciso atentar também para o que não é dito por palavras.

No entanto, o paradoxo maior da expressão "ouvir a voz das crianças" reside não apenas no facto de que ouvir não significa necessariamente escutar, mas no facto que essa "voz" se exprime frequentemente no silêncio, encontra canais e meios de comunicação que se colocam fora da expressão verbal, sendo, aliás, frequentemente infrutíferos os esforços por configurar no interior das palavras infantis aquilo que é o sentido das vontades e das ideias das crianças. Mas essas ideias e vontades fazem-se "ouvir" nas múltiplas outras linguagens com que as crianças comunicam. Ouvir a voz é, assim, mais do que a expressão literal de um acto de auscultação verbal (que, aliás, não deixa também de ser), uma metonímia que remete para um sentido mais geral de comunicação dialógica com as crianças, colhendo as suas diversificadas formas de expressão (SARMENTO, 2011, p. 28).

Podemos perceber que realizar estudos relacionados às crianças significa se preocupar em realizar novas discussões, pois o reconhecimento da infância como categoria geracional, dotada de significados, com características próprias das identidades infantis, gera a preocupação com as discussões que delinearão tais estudos.
A Sociologia da Infância então, nos auxiliará nesse processo sobre o reconhecimento da importância de ouvir as crianças como forma de inserção como sujeitos nos processos educacionais, além de ser importante para a compreensão de como deve se realizar a formação crítica de nossas crianças, objeto central desse estudo.

Partindo de todos esses pressupostos, o objetivo geral desse artigo é refletir sobre as possibilidades de promover uma formação crítica de nossas crianças sobre nossa sociedade pelo ambiente escolar, mais especificamente no I Ciclo do Ensino Fundamental, à luz da Sociologia da Infância.

Esse trabalho ainda terá como norte as seguintes perguntas: Como a história da infância influenciou a visão de criança que temos nos contextos educacionais até os dias de hoje? Como as mudanças que estão acontecendo na sociedade podem ser importantes para a formação crítica de nossas crianças? Quais os problemas que o professor encontra para motivar o aluno a pensar, refletir e articular metas e ações para intervir em sua realidade?

Com tantas mudanças acontecendo hoje em nossa sociedade, há uma série de influências que afetam diretamente a formação crítica de nossas crianças, como as mídias (GIRARDELLO, 2005) e a globalização (SARMENTO, 2004), por exemplo. Além disso, muitas conceituações e práticas presentes hoje nas escolas possuem raízes históricas, principalmente com relação à visão de que a criança é um ser que não possui conhecimentos (AZEVEDO, 2012) e, com isso, a metodologia empregada ocorre, na maioria das vezes, pautadas em pensamentos "adultocêntricos"

Partimos do pressuposto que o professor, como principal mediador do processo educacional, pode provocar a formação crítica das crianças por meio de debates e reflexões feitas com seus alunos por meio de sua prática pedagógica. Para isso, é preciso mudar, em muitos momentos, nossa visão de criança na sociedade e pensar sobre a importância do processo de mediação ocorrido nas salas de aula.

\footnotetext{
${ }^{1}$ Conforme Delgado e Müller (2008), "adultocêntrico" é um termo usado pelas autoras para definir uma sociedade predominantemente dominada pelos adultos, em que pouco se escutam as vozes das crianças.
} 
2 A infância nos primórdios: primeiras transformações

Por meio de estudos bibliográficos, como os de Ariès (1978), vimos que o conceito de infância e criança passou por várias transformações até chegar ao conceito que temos hoje. Sendo assim, é de grande importância termos esse conhecimento de infância desde os primeiros tempos, para compreendermos melhor o conceito atual que temos de infância.

Houve uma época em que as crianças eram tratadas com um sentimento superficial, como nos conta Ariés (1978):

$$
\begin{aligned}
& \text { Contudo, um sentimento } \\
& \text { superficial da criança a } \\
& \text { que chamei de } \\
& \text { 'paparicação' } \\
& \text { reservado à criancinha em } \\
& \text { seus primeiros anos de } \\
& \text { vida, enquanto ela ainda } \\
& \text { era uma coisinha } \\
& \text { engraçadinha. As pessoas } \\
& \text { se divertiam com as } \\
& \text { crianças pequenas como } \\
& \text { um animalzinho, um } \\
& \text { macaquinho impudico. Se } \\
& \text { ela morresse então, como } \\
& \text { muitas vezes acontecia, } \\
& \text { alguns podiam ficar } \\
& \text { desolados, mas a regra } \\
& \text { geral era não fazer muito } \\
& \text { caso, pois outra criança } \\
& \text { logo a substituiria. A } \\
& \text { criança não chegava a sair } \\
& \text { de uma espécie de } \\
& \text { anonimato (ARIÈs, 1978, } \\
& \text { p.10). }
\end{aligned}
$$

Ainda segundo Ariès (1978), no período Medieval se percebe um aumento de filhos gerados por família e um comportamento diferente (se comparado com os dias atuais) para com as crianças, além de nesse período a taxa de mortalidade infantil ser muito alta. Eram poucas as pessoas que davam importância às questões da infância e tais problemas não eram sanados. Sendo assim percebemos que as famílias e a sociedade Medieval, não davam importância para a infância, ou seja, não apresentava nenhum significado ou, pelo menos, o significado no qual estamos hoje acostumados.

Registros mostram que até mesmo nos trabalhos artísticos as crianças eram ignoradas. Até o século $\mathrm{XI}$, por exemplo, a arte desconhecia por completo a infância. Nas representações iconográficas eram registrados vários momentos, várias pessoas já adultas, mas não havia espaço nesse contexto para as crianças. "É mais provável que não houvesse lugar para a infância nesse mundo" (ÁRIES, 1978, p.50).

$\mathrm{Na}$ Idade Média as crianças que sobreviviam tinham uma fase curta de infância, pois logo eram separadas das famílias, entravam no mercado de trabalho e passavam a fazer atividades como dos adultos.

$\mathrm{Na}$ idade média, no início dos tempos modernos, e por muito tempo ainda nas classes populares, as crianças misturavam-se com os adultos assim que eram considerados capazes de dispensar a ajuda das mães ou das amas, poucos anos depois de um desmame tardio ou seja, aproximadamente, aos sete anos de idade. (ARIES,1978,p.275)

Nesse período a criança era considerada como um adulto em miniatura, ou seja, um adulto de tamanho reduzido. Os adultos se relacionavam com as crianças da mesma forma que se relacionavam entre si, sendo as crianças expostas a todo e qualquer tipo de situação, como ações grosseiras, discriminações, trabalhos intensos e até jogos sexuais (ARIÈS, 1978).

Foi no período da Idade Moderna que o conceito de infância começa a mudar, passando a ser reconhecido como uma categoria social, como afirmam Sarmento e Pinto (1997). As crianças e as infâncias existem há muito tempo, mas a ideia de infância como construção social é bastante recente.

Assim diante do que vimos até aqui, podemos concluir que o conceito de infância passou por vários processos de mudanças e de uma maneira bem lenta para a sua evolução. Também vale a pena ressaltar o significado da palavra infância que de acordo com Cordeiro e Coelho (2007):

[...] a definição da palavra infância, oriunda do latim infantia, significa 'incapacidade de falar'. Considerava-se que a criança, antes dos 7 anos de idade, não tinha condições de falar, de 


\begin{abstract}
expressar seus
pensamentos, seus sentimentos. Desde a sua gênese, a palavra infância carregava consigo o estigma da incapacidade, da incompletude perante os mais experientes, regulando-lhes uma condição subalterna diante dos membros adultos. Era um ser anônimo, sem um espaço determinado na sociedade. (CORDEIRO; COELHO, 2007, p 884).
\end{abstract}

Portanto, vimos que o descaso com as crianças pelos adultos era grande, sendo que isso já partia desde o significado da origem da palavra "infância", ou seja, que considerava as crianças incapazes. Esse conceito só veio começar a mudar após o período da Idade Moderna, evoluindo aos poucos e mudando essa concepção de infância.

\subsection{As Primeiras Crianças do Brasil}

Houve no Brasil uma preocupação, mais especificamente no século XIX, no qual os filhos de ricos tinham que continuar os negócios de seus pais, enquanto que os filhos dos pobres tinham que ajudar no trabalho do campo. Preparava-se a criança para o futuro, em que a mesma era vista como valor econômico e, já no século $X X$, pensava-se no papel da criança perante a sociedade, em como ela se encaixaria numa diferença entre a infância e a idade adulta (AZEVEDO, 2016).

Assim, nessa passagem do século $X I X$ para o século $X X$, o pensamento sobre a infância se transformou, no qual se abriu uma maior discussão sobre fatos em que a criança não poderia ser educada apenas pela família, afetando, então, as classes mais pobres, pois suas condições não eram boas. O resultado foi um interesse de muitos setores da sociedade em tudo que se referia à infância (KUHLMANN JÚNIOR, 1998).

Finalmente, na década de 1990, com a implantação do Estatuto da Criança e do Adolescente - ECA, as denúncias de violência contra a criança e o adolescente, assim como as explorações de crianças no trabalho, ficaram mais visíveis. A infância tem, então, várias concepções em torno das relações históricas, políticas e culturais, e como essas relações afetaram a construção da criança na sociedade, o que causou uma evolução na concepção de infância, especialmente ao se dirigir ao desenvolvimento infantil e como ela seria tratada no ambiente familiar e social. Portanto, foi a partir do século XX que a infância passou a ser vista como uma categoria geracional, que tinha necessidades específicas daquela etapa da vida (AZEVEDO, 2016).

Compreendendo que a infância é construída pelas fases da vida, mas que também existem influências que mudam, já que essa infância será transformada segundo o espaço que ela ocupa, é, sobretudo, na Independência do Brasil que se inicia uma discussão sobre os direitos da criança e do adolescente, como a primeira lei imperial penal - as leis viam a infância como uma fase passageira, no qual seriam corrigidos rigorosamente como se fossem adultos (AZEVEDO, 2016).

Se olharmos a infância desde o descobrimento do Brasil, a criança já era explorada, pois elas tinham que trabalhar para os portugueses como adultos. As crianças serviam, então, como mão-de-obra barata, não tinham direito algum, nem importância na sociedade, principalmente indígenas e negros que foram os que mais sofreram com a escravidão. Além disso, eram vistas, muitas vezes, como animais, pois segundo Ramos (2010) a expectativa de vida das crianças portuguesas entre os séculos XIV e XVIII era em torno de catorze anos, num contexto em que a grande maioria das crianças nascia e vivia, geralmente, até os sete anos de idade.

Durante a escravidão, para os senhores, os filhos de escravos não tinham nenhum valor, eram considerados como prejuízo, e não eram raras as separações das famílias dos escravos naquela época. Mais adiante, depois de muito tempo de sofrimento dessas crianças, houve um apoio das leis visando diminuir a criminalidade e tempos depois, após o golpe militar, pensou-se na criança como fator do subdesenvolvimento, porém não estavam pensando na infância e sim no país, em seu desenvolvimento, pois aquelas crianças, caso se tornassem abandonadas ou delinquentes, atrapalhariam o progresso do Brasil (AZEVEDO, 2016).

Com a criação do Estatuto da Criança e do Adolescente - ECA, ocorreram mais mudanças, pois em muitos contextos o problema parecia ser outro: os pais não possuem mais tanto tempo para os filhos. A mudança na 
sociedade, como a violência urbana, os problemas das grandes cidades, a globalização e o avanço tecnológico, fazia com que as relações entre pais e filhos se transformassem de forma radical (DEL PRIORE, 2010).

A criança hoje também é influenciada ao consumo e as mídias estão idealizando um novo mundo. $\mathrm{O}$ apelo da televisão, por exemplo, faz com que a infância seja interrompida e as crianças reajam de forma adultizada, prejudicando, muitas vezes, seu desenvolvimento social, pois se tornam "pequenos adultos" que não refletem sobre a sociedade e, em geral, ficam presas as ideologias dos meios de comunicações do mundo moderno, como veremos mais adiante nesse estudo. Por enquanto, faremos ainda uma breve exposição histórica sobre as crianças e as primeiras escolas no Brasil.

\subsection{As crianças e as primeiras escolas do Brasil.}

No contexto da chegada dos Jesuítas no Brasil, a criança era vista como uma folha de papel branco. Com isso a Companhia de Jesus tomou para si o papel de educar e moldar as crianças de forma que viessem a ser submissas e disciplinadas perante a sociedade. Era uma instrução religiosa, e havia diferença de como se educar. Segundo Faria (2005 p. 33)

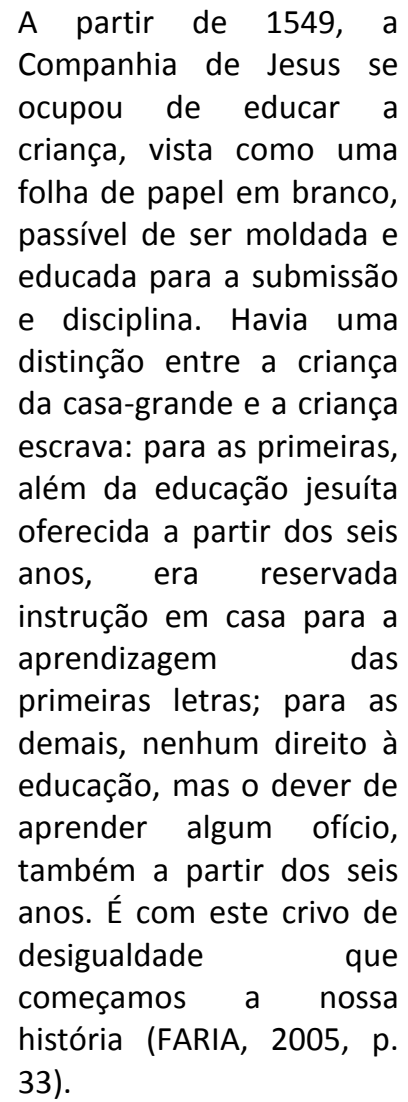
Companhia de Jesus se a folha de papel em branco, passível de ser moldada e distinção entre a criança da casa-grande e a criança além da educação jesuíta oferecida a partir dos seis anos, era reservada instrução em casa para a primeiras das demais, nenhum direito à educação, mas o dever de aprender algum ofício, também a partir dos seis nos. E com este crivo de desigualdade que história (FARIA, 2005, p. 33).
O conceito de "infância", como já vimos, só veio à tona a partir da idade moderna (XVII e XVIII) e após a Idade Média a criança passou a ser vista, aos poucos, como um ser social, conquistando assim, um lugar na família e na sociedade. Porém as políticas destinadas às crianças no Brasil eram insuficientes para atender suas necessidades de desenvolvimento e formação do indivíduo (SILVA; FRANCISCHINI, 2012).

Em 1874, várias Câmaras Municipais do Brasil tiveram a iniciativa de fazer algo pelas crianças enjeitadas, iniciativa essa que tentaria destinar determinadas quantias de dinheiro a essas crianças, que se encontravam em instituições de caridade como a Roda dos Expostos. Com isso a criança passou a ser vista com outro olhar, visando nela o futuro melhor do país. Para isso, era necessário melhorar e promover uma melhor qualidade de vida a elas, garantindo um futuro saudável e promissor. O que era visto como forma de descaso passou a ser reavaliado para que ocorressem as melhorias (SILVA; FRANCISCHINI, 2012).

A partir desse momento ocorrem diversas mudanças, e se pensa em um local para atender as crianças pobres com objetivo de, além de cuidar, também possibilitar que as mães adentrassem o mercado de trabalho. Surgem então as creches e também os jardins de infância no Brasil, destinados às crianças de baixa renda com caráter médico/assistencial (SILVA, FRANCISCHINI, 2012).

As creches atendiam crianças das $05 \mathrm{~h} 30$ às $20 \mathrm{~h} 30$, de segunda a sábado, exceto em dias de festas e feriados, e as mães amamentavam seus filhos apenas duas vezes ao dia. Os primeiros jardins de infância nascem no Brasil em 1897 em São Paulo, destinados as crianças de quatro a sete anos.

O Jardim da Infância ou Kindergarten, embasado nas ideias do filósofo alemão Friedrich Wilhem August Froebel, tinha como objetivo e prática educar os sentidos das crianças. Utilizando jogos, cantos, danças, marchas e pinturas, o intuito era de despertar o divino que existia no interior da alma humana. (SILVA, FRANCISCHINI, 2012 p. 5) 
Em 1909 surge primeira creche pensada exclusivamente para filhos de operários e atendia crianças até dois anos, mas ainda com caráter médico/assistencialista. No início do século XX o Estado criou sua primeira política pública para a infância pobre, por meio do $1^{\circ}$ Código de Menores e o Juízo de Menores. Como afirma Santos (1988):

$$
\begin{aligned}
& \text { Olhando toda essa } \\
& \text { trajetória - do momento } \\
& \text { em que sociedade ganhou } \\
& \text { consciênciarda } \\
& \text { especificidade da infância } \\
& \text { e depois, na virada do } \\
& \text { século, quando ganha } \\
& \text { consciência da noção de } \\
& \text { infância pobre e mais } \\
& \text { tarde, na década de 20, } \\
& \text { quando se cria a } \\
& \text { especificidade da infância } \\
& \text { menorizada - percebe-se } \\
& \text { que estas concepções tem } \\
& \text { sido um peso muito forte } \\
& \text { na definição de políticas } \\
& \text { para crianças e e } \\
& \text { adolescentes. (SANTOS, } \\
& \text { 1988, p.20). }
\end{aligned}
$$

Com a migração urbana o país apresenta vários problemas, tais como o crescimento desorganizado das cidades e muitas crianças que ainda viviam nas ruas. Havia uma alta taxa de mortalidade, criminalização e nenhuma preocupação de fato com a educação e o processo de aprendizagem de crianças asiladas (AZEVEDO, 2016).

A preocupação com o "futuro da nação", em tirar as crianças das ruas, ocorria no âmbito educacional, mas na realidade pouco se fazia. Crianças pobres representavam perigo e ameaça para o progresso do país, pois poderiam transmitir seus hábitos nada condizentes com aquilo que era aceito na sociedade, e com isso, ameaçar o progresso tão almejado.

Cuidar dessas crianças era fundamental para que elas estivessem protegidas de todos esses perigos e não reproduzissem, mais tarde, a realidade dos seus lares pobres, vistos como delinquentes, além de não constituírem, no futuro, uma ameaça à sociedade, sua ordem e bem estar. (KUHLMANN JUNIOR, 2000).

A história da educação para as crianças no Brasil caminhou junto com o assistencialismo, pois nosso país veio de uma linhagem pobre, sendo que as dificuldades eram imensas e a preocupação mínima. Por meio de criações de instituições voltadas para o acolhimento de crianças marginalizadas, com a chegada do progresso começou a se pensar numa melhor qualidade de vida para os pequenos. $O$ fato é que não é de hoje que existem tantos problemas enfrentados pelas crianças de baixa renda - é algo de longa data e de preocupação de poucos.

\section{Surgimento da Sociologia da Infância e seus significados}

A ideia de infância é atual, pois a criança era vista, em muitos tempos da história humana, como um ser sem lugar na sociedade, um ser biológico que pertencia em alguns contextos ao universo feminino, até serem introduzidos na adultez precoce no contexto do Renascimento e se tornando autônomo no século das luzes. (ARIÉS, 1978).

O modernismo produziu métodos sobre a administração da infância, as atitudes e os comportamentos quanto à criança, que tinha sua vida condicionada segundo a sociedade. Assim a criança obteve autonomia por meio de instrumentos simbólicos regularizados, como por exemplo, com a Convenção dos Direitos das Crianças e agências internacionais como o "Fundo das Nações Unidas para a Infância" - UNICEF e a "Organização Mundial da Saúde" - OMS. (CHAMBOREDON; PRÉVOT, 1982; SIROTA, 2001; SARMENTO, 2002).

A 2a Modernidade, conforme Sarmento (2004) caracteriza-se pela alteração dos paradoxos da infância ao construir um novo olhar sobre a criança, além de provocar uma reinstitucionalização da infância - a criança passou a ser vista tendo mais participação no meio social.

Com as mudanças na economia houve alterações nas condições de vida das crianças e o lugar delas perante a sociedade já não é o mesmo. Assim, reinstitucionalizar a infância considerando, por exemplo, a criança na economia, foi introduzida principalmente a partir da produção com o trabalho infantil (pensando da pior forma), mas também foram colocadas no marketing, por meio do qual as crianças eram utilizadas para propagandas de produtos, na finalidade de influenciar o consumo. (SARMENTO, 2004).

O processo de institucionalização da criança foi cheio de contradições e no caso do Brasil, isso está relacionado ao processo de colonização, em que as escolas eram pensadas 
apenas para determinada classe social, numa realidade em que os mais pobres tinham que trabalhar e, consequentemente, não obtinham acesso à escola. (DEL PRIORE, 2010).

A grande questão no estudo das Culturas da Infância ${ }^{2}$ (um dos objetos de pesquisa da Sociologia da Infância) é como se veem essa autonomia infantil perante o mundo dos adultos, tendo assim várias controversas, pois as Culturas da infância se constituem por meio das interações com os pares e o adulto, construindo diversas formas de relações. Sendo assim causou-se a universalização das Culturas da Infância, passando os limites da inclusão cultural de cada criança, segundo o qual elas criam suas ordens sociais instituinte, de acordo com o que é produzido para si, ao seu redor (FERREIRA, 2002).

Sarmento (2004) define alguns pontos importantes a serem discutidos quando falamos de Culturas da Infância. Para o autor, essa discussão teórica e epistemológica é um desafio científico, e tem 4 eixos centrais que estruturam essa reflexão: a Interactividade, a Ludicidade, a Fantasia do real e a Reiteração.

$\mathrm{Na}$ interatividade as crianças aprendem por meio da interação com outras crianças e em lugares que são comuns a um determinado grupo. Aqui percebemos a importância da cultura de pares $^{3}$, que permite que a criança expresse seu mundo. Nesse caso, é importante também ressaltar que é nesse momento que as crianças "partilham conhecimentos, rituais e jogos que vão sendo transmitidos de uma geração de crianças para a seguinte" (SARMENTO, 2004, p. 15). Por esse motivo ocorre o fato de que algumas brincadeiras tradicionais como o pião e a pipa são ainda tão conhecidas em plena era dos jogos eletrônicos - são comportamentos e tradições que nascem com as Culturas Infantis e que não dependem da comunicação de adultos para serem compartilhadas e passadas adiante.

O jogar e o brincar fazem parte do eixo ludicidade, um dos elementos principais das Culturas Infantis de acordo com Sarmento (2004). Para as crianças, brincar é coisa séria e não há

\footnotetext{
2 O termo "Culturas da Infância" (SARMENTO, 2004) ou "Culturas Infantis" (CORSARO, 2011) surgiu na década de 1980, com os primeiros estudos da Sociologia da Infância, e é compreendido como o processo de produção cultural que é construído e estabelecido pelas crianças nas relações com seus pares, além de considerar como a criança pode ser entendida hoje como produtora de cultura e como sujeito ativo no contexto social.

3 Segundo Corsaro (2011) a "Cultura de pares" são atividades, rotinas, artefatos, valores e preocupações que as crianças fazem com as outras crianças, ou seja, elas reproduzem o que the e passado em seu meio, ajudam na produção e mudança cultural.
}

para elas diferenças entre suas brincadeiras e as coisas entendidas por nós adultos como sérias. Os brinquedos aqui também exercem um importante papel, mesmo os tradicionais que vem sendo cada vez mais substituídos pelos brinquedos industriais, pois o que importa é a natureza interativa do brincar que é, segundo o autor, um dos primeiros elementos das Culturas da Infância e o brinquedo é seu acompanhante nesse processo.

Pelo brincar e por meio dos brinquedos ocorre a produção das fantasias infantis, outro elemento importante, agora ligado ao eixo fantasia do real. É aqui que a criança constrói, pelo mundo do faz-de-conta, sua visão social, atribui significados às coisas e permite à criança que ela continue o jogo da vida em condições aceitáveis para ela. Esse processo de imaginação do real é um elemento central da capacidade de resistência que as crianças possuem frente às mais diversas situações do mundo, inclusive aquelas mais trágicas, como por exemplo, no caso de uma estrela que leva ao céu uma pessoa querida, uma criança que brinca com sua boneca em meio a destroços de guerras civis ou desastres naturais (SARMENTO, 2004).

O último eixo é o da reiteração e está ligado ao tempo da criança em suas rotinas de ação. Esse tempo é recursivo, sem medida, revestido de novas possibilidades e capaz de ser reiniciado e repetido sempre que quiserem. Isso ocorre por meio das práticas ritualizadas presentes nos jogos e nas brincadeiras (um começa, depois o outro), pelas propostas de continuidade (e depois, e depois...) ou por rupturas que são logo resolvidas ("não brinco mais com você"). Além disso, durante essas rotinas são estabelecidas regras e protocolos de ação - trocam-se segredos, decodificam-se sinais de vida em grupo e estabelecem-se novos pactos, além da recriação das rotinas por meio de brincadeiras, jogos e rituais das crianças mais velhas para as crianças mais jovens, permitindo assim que toda a infância se reinvente e se recrie, formando assim um ciclo que nunca se acaba.

Partindo agora para outra discussão importante - a questão de dar voz às crianças nos processos acadêmicos e educacionais - devemos nesse caso desconfiar das ideias de uma infância absoluta e sim construir discursos de uma infância diferente. Para isso, é preciso que a sociedade se transforme para ouvir a voz das crianças, rompendo as representações hegemônicas, não aceitando muitas das 
ideologias que tanto perduraram (e ainda perduram em muitos contextos) sobre as crianças, pois elas são diferentes umas das outras e preenchem vários tempos e espaços onde estão inseridas (SARMENTO, 2004).

Segundo Sarmento (2002), um dos principais objetivos da Sociologia da Infância é procurar entender o processo chamado por ele de "reprodução interpretativa", que é construída pela identidade de cada criança e o estatuto da infância gerada pela sociedade que é inserida. A "reprodução interpretativa" implica compreender que a socialização não é apenas uma questão de adaptação e internalização, mas trata-se também de um processo de apropriação, reinvenção e reprodução, ocorrida por meio de negociações, informações compartilhadas e pela produção da cultura com os adultos e com os seus pares. 0 conceito de reprodução interpretativa significa, então, compreender que as crianças contribuem para a preservação (ou reprodução) social e também para a mudança social.

Sabemos que o espaço da escola também sofreu mudanças - antes era construído com intuito que fornecer o conhecimento seguindo os princípios da sociedade, o que deve ser bom a princípio para uma determinada comunidade. Sendo assim, a organização da cultura da escola é importante não somente para que estejam na instituição, mas sim na construção da sua democratização.

James e Prout (1997) defendem que uma das coisas mais importantes a se considerar na quebra de paradigmas em relação à infância seria dar voz as crianças enxergando-as como cidadãos de direitos, assim como os adultos. Isso significa ver a criança ativa na construção de sua vida social, sendo cada uma diferente das outras, independente do meio onde estão inseridas, acabando com a ideia da infância inocente facilmente influenciada, pois elas estão em contato com muitos dos mesmos conhecimentos partilhados pelos adultos, como as novas tecnologias, e se mostram, muitas vezes, bem mais habilidosas e com muita facilidade em se desenvolver e adquirir tantas informações por meio delas.

Existem várias discussões sobre os significados da Sociologia da Infância - algumas controversas, como se a infância é a fase mais importante da vida, como desenvolvê-la, como estimular sua autonomia e sua democratização na sociedade, tendo uma preocupação com essa fase na vida das crianças. Porém, o foco é evidenciar a criança no ambiente social, local onde ela não tem voz em muitos momentos.

Neves (2010) argumenta que a criança além de internalizar os valores e as culturas que Ihe são apresentadas, ela se torna cada vez mais capaz de construir um mundo por meio do pensamento crítico. As crianças recebem informações não apenas dos adultos, mas também na interação com os pares, ocasionando influências formativas nas interações intrageracionais e intergeracionais, ou seja, a criança adquire o conhecimento com a experiência com o outro e assim vai aprendendo e formando significados daquilo para ela.

Portanto a interação com os pares é muito importante, pois ela poderá se desenvolver muito mais ainda, já que a criança não aprende somente com o adulto, mas também com as outras crianças, cada uma mostrando sua cultura que Ihe foi passada, e assim divididas com o outro (FERNANDES, 2004).

Então, os sociólogos da Sociologia da Infância procuram encontrar na infância a autonomia da cultura, os princípios que definem as crianças, além de compreenderem como esses fatores influenciam o desenvolvimento na sociedade e o que podemos fazer para ajudar as crianças a terem voz em nossa sociedade.

\subsection{A criança e a cidadania nos processos educacionais}

Como visto até agora nesse estudo, atualmente as crianças precisam ser vistas com outro olhar, além de ser reconhecidas como cidadãos de direitos:

Podemos afirmar que se trata de uma visão colonizadora face à infância, já que a criança é considerada como um receptor passivo, uma realidade social que se caracteriza pela sua dependência face a outros colectivos, o que limita o desenvolvimento da ideia de participação das crianças. (TOMÁS, 2007, p. 7).

Vimos que as crianças são em muitos momentos limitadas pelos adultos e são eles que tomam as decisões por conta própria, sem deixar a criança opinar naquilo que a favorece. Nesse caso, a criança fica sendo um receptor passivo o 
que acaba bloqueando sua participação ativa na sociedade, seus pensamentos e sua autonomia. Assim, vimos que muitos contextos ainda não tratam as crianças como cidadãos de direitos, o que segundo Tomás (2007):

[...] significa estar
presente, reivindicar
participação nos processos
sociais e políticos da
comunidade. Cidadão é
aquele que assume esse
estatuto em todas as
esferas da vida social, ou
seja, no bairro onde
reside, na empresa ou
estabelecimento onde
trabalha e na escola. A
aquisição de
comportamentos cívicos é
uma questão que não é
nem inata nem de
doutrinação, mas algo que
se constrói no exercício
dos direitos e dos deveres
de cidadania: aprende-se a
democracia praticando-a.
Não pode existir cidadania
participativa sem
socialização democrática.
(TOMÁs, 2007, p. 13).

Desse modo precisamos mudar muitos de nossos hábitos com relação às crianças, visto que, na maioria das vezes, elas não estão tendo os seus direitos de cidadãos, sendo necessário, desde pequenas, inseri-las como cidadãos participativos e reflexivos, independente de onde estejam. De acordo com Tomás e Soares (2004), "o direito de participação da infância no quotidiano é um princípio orientador fundamental, ou seja, contribui para assegurar o cumprimento de todos os outros direitos. (...) A participação da infância apresenta-se, assim, como condição para se concretizar a cidadania na infância" (TOMÁS; SOARES 2004, p.13).

Podemos observar, claramente, que a questão dos direitos em relação às crianças e a sua participação na infância deve se estender a todas as crianças sem nenhum tipo de restrição. Porém, em nossa realidade, somente algumas estão gozando desse direito e a grande maioria é vista simplesmente como sujeitos inocentes que não têm competência de decidir cabendo, portanto, aos adultos as tomadas de decisões.

As escolas atualmente podem ser consideradas um dos principais ambientes em que a criança vai ter contato com a socialização e a cidadania. Nesse sentido, podemos entender que cabe a essas instituições, bem como aos professores, oferecer e dar condições para elas participem de decisões coletivas que Ihe dizem respeito e tornar cidadãos ativos, assim como nas palavras de Sarmento (2011):
O exercício da cidadania é hoje entendido como um dever e um direito a usufruir em qualquer contexto educativo. No interior da escola todos os seus protagonistas são convidados a exercitar práticas de cidadania. Não se exclui ninguém, mesmo os mais pequenos interlocutores têm o direito a participar nas decisões que, por alguma razão, possam ter influência na sua vida académica. A cidadania da criança constitui-se deste modo como um desafio à mudança das estruturas políticas, educativas e sociais, à transformação das instituições e à renovação cultural (SARMENTO, 2011, p. 4).

Ou seja, para que tenhamos mudança na sociedade precisamos investir na infância. Nesse sentido, segundo Sarmento (2011) "para se assumir verdadeiramente a cidadania da criança é importante ouvir a sua voz e valorizar a sua participação no mundo que a rodeia, afirmando valores e os direitos das crianças".

As escolas precisam reconhecer os direitos das crianças e promover um ambiente que favoreça a cidadania e a democracia. Trabalhar com as crianças mostrando os seus direitos significa compreender que elas devem participar, refletir e irem à busca daquilo que dizem a seu respeito (BRAYNER, 2001).

Realmente o professor não pode se considerar o único detentor do saber, mas sim um mediador que vai proporcionar um ambiente em que os alunos vão construindo o conhecimento a partir de trocas de experiências e por meio de pesquisas e com a mediação do professor. É muito importante o professor ouvir a voz da criança não só durante as aulas, mas também antes de fazer e refazer o planejamento 
e os planos de aula, pois a escuta da voz do aluno vai facilitar e fazer com que os trabalhos a serem desenvolvidos sejam mais eficazes (AZEVEDO, 2016).

Nossa sociedade está se perdendo com relação à formação crítica de nossos alunos, e podemos começar a reverter essa situação pelas crianças: ensiná-las a serem cidadãos. Segundo Tomás (2007) precisamos:

Educar na cidadania e democracia e não para a cidadania e democracia, considerando que as crianças têm um papel activo no processo, implica a promoção de espaços e oportunidades que promovam competências e concepções elas próprias democráticas e cidadãs, assumindo direitos e deveres considerados como um legado cultural e a interiorização e apropriação por parte dos actores sociais dessas práticas. Isto implica participação activa nos processos públicos, ter acesso às informações e conhecimentos necessários à participação cidadã, ter formação, adquirir conhecimentos $\mathrm{e}$ saberes sobre direitos, participação, cidadania e democracia (TOMÁs, 2007, p.13).

Quando as escolas refletirem sobre suas práticas pedagógicas e passarem a valorizar as ideias e participação das crianças, vamos instigar os pequenos a serem autônomos e cidadãos reflexivos. "Ao participar na escola, a criança por um lado procura informar-se e tende a cooperar, a investigar, a exprimir-se, no sentido de compreender aspectos que se confinam ao seu estatuto de cidadã". (FREIRE, 2011, p.6).

Portanto, também é papel das escolas estimular a participação da criança nas tomadas de decisões, seja nas aulas, nos planejamentos, na gestão e outros - em todos os casos elas irão perceber e conhecer a importância da sua opinião. "Cremos que se forem garantidas as condições necessárias para participar nas decisões que afectam a sua vida, a criança aprende a ser cidadã pela cidadania e começa a participar pela participação". (FREIRE, 2011, p.9).

Delgado e Müller (2008) afirmam que "o campo da Sociologia da Infância tem nos ensinado que as crianças são atores sociais porque interagem com as pessoas, com as instituições, reagem frente aos adultos e desenvolvem estratégias de luta para participar no mundo social", ou seja, as crianças desde pequenas e começam a se socializar e com o avanço tecnológico elas adquirem muitos conhecimentos e informações. Esses são um dos motivos, conforme Tomás (2007) afirma, no qual - paradigma de controle e negação da capacidade das crianças deva ser superado:

Assim, podemos afirmar
que a mudança do
paradigma de controlo e
de negatividade para com
as crianças para um
paradigma que considere
as crianças actores sociais
participativos, não só é
necessária mas é urgente,
para a criação e
implementação de um
tempo onde as crianças
sejam consideradas
cidadãs activas e, por isso,
tenham o direito de fazer
escolhas informadas,
tomar decisões relativas à
organização dos seus
quotidianos e influenciar a
tomada de decisões dos
adultos, sempre que estas
de alguma forma lhe
digam respeito. (TOMÁs,
2007, p.3)

Também é muito importante incluir as crianças nas pesquisas acadêmicas, pois tem se a necessidade de buscar novos conhecimentos em relação à infância, quais são os direitos da criança, a sua capacidade e principalmente em torná-los cidadãos desde a infância (AZEVEDO; BETTI, 2014).

Segundo Delgado e Müller (2008, p. 3) "para os sociólogos da infância é importante considerar o ponto de vista das crianças nas pesquisas, o que também exige certo abandono do olhar centrado no ponto de vista do adulto". É fato que as pesquisas acadêmicas, na maioria das vezes, centram-se no pensamento do adulto. As crianças são capazes, jamais devemos considera- 
las como receptores passivos das influencias sociais, culturais, políticas e até econômicas.

Sendo assim, mediante a tudo o que discutimos até o momento, é preciso reconhecer que a criança pode sim opinar sobre assuntos que Ihe dizem respeito e que, até o contexto atual, sempre foi mais comum que as tomadas de decisões partissem dos adultos. Na prática, podemos citar o estudo realizado por Azevedo (2016), pois em vários momentos as crianças opinaram sobre as atividades planejadas.

No caso desse estudo acadêmico realizado por Azevedo (2016), pode ser notado o que Sarmento (2013) chama de "cidadania infantil". Nesse caso, as escolas podem conseguir se tornar um lugar engajado pelos direitos da criança, "porque é aí o lugar das culturas infantis e da plena afirmação da alteridade" (SARMENTO, 2013, p. 12).

Se estivermos dispostos a ver as crianças como cidadãos de direitos plenos, precisamos enxergá-las como capazes de opinar, sobretudo nas escolas. Ferreira e Sarmento (2008) nos lembram que as instituições para a infância têm sido conduzidas, na maioria das vezes, por ideias e ações adultas apenas, o que contribui para o predomínio de uma "(in)visibilidade" (FERREIRA; SARMENTO, 2008, p. 68) da infância - isso significa compreender que, apesar de as crianças existirem e estarem nas instituições, a inclusão de suas ideias nas tomadas de decisões é mínima, o que faz com que elas continuem em situação de invisibilidade e desconhecimento.

Para que essa realidade comece a se transformar, é preciso que esse reconhecimento das crianças como pessoas se torne um interesse central das discussões e decisões tomadas pelas instituições que lhe atendem. A cidadania na infância implica uma cultura que permita a inclusão democrática das crianças em todos os domínios da vida social e pessoal, ou seja, as instituições que lhes atendem, sejam escolas, creches, clubes, instituições de acolhimentos temporário ou permanente, entre outros, precisam ampliar o espaço de participação das crianças em seus contextos. Em suma, é preciso ouvir (e considerar) a voz das crianças.

\section{CONSIDERAÇÕES FINAIS}

Concluímos que nós, enquanto professores, temos possibilidades de promover uma formação crítica de nossas crianças sobre nossa sociedade no ambiente escolar, pois dentro de uma sala de aula estamos com várias crianças.
Devemos aproveitar essa oportunidade e tornar o ambiente escolar um espaço de aprendizagem utilizando várias ferramentas e metodologias para atender todos os alunos e formá-los cidadãos críticos, reflexivos e conscientes de que todas as suas ações têm uma implicação, tanto positiva quanto negativa, e assim somos sujeitos com direitos e deveres.

No decorrer da pesquisa tivemos a oportunidade de refletir sobre a memoria da infância na sociedade brasileira e percebemos que houve bastante evolução em razão do conhecimento e valorização da infância, visto que nos primórdios, as crianças não eram reconhecidas como cidadãos com direitos $\mathrm{e}$ deveres. Também, não se tinha um sentimento pela criança como vemos nos moldes atuais, porque a viam como um ser que, se morresse, logo seria substituído por outro e depois, aproximadamente a partir dos sete anos de idade, tinha-se um olhar como "adulto em miniatura", por meio do qual entrava no mercado de trabalho e desenvolvia as tarefas de um adulto. Aqui entendemos que a criança não gozava de muitos direitos, como os prazeres das atividades lúdicas, por exemplo, assim como brincadeiras e jogos.

Precisamos romper com esses paradigmas, e o papel do professor é mediar o conhecimento e motivá-los, porque devemos levar em conta que as crianças, quando entram na escola, já trazem consigo uma bagagem de conhecimentos que são adquiridos no meio ao qual elas convivem, seja por meio das mídias, dos recursos tecnológicos, entre outros. Por esse motivo, cabe ao professor fazer uma sondagem do que o aluno já sabe e a partir daí desenvolver um trabalho propondo novos conhecimentos $\mathrm{e}$ propondo a aquisição de outras habilidades.

Por fim é preciso uma mudança em relação à visão que temos, muitas vezes, sobre a criança. Elas precisam ser reconhecidas como sujeitos no processo educacional, pois entendemos a importância de ouvi-las durante os vários processos educacionais. Isso pode auxiliar outras pessoas que estão em processo de formação inicial e também os professores que já estão dando aulas e que ainda não refletiram sobre a infância e a importância de se ouvir a voz da criança para planejar suas aulas e desenvolver seus projetos. 


\section{REFERÊNCIAS}

ARIÈS, P. História social da criança e da família. Rio de Janeiro: Zahar, 1978.

AGUIAR, C. M. Educação, Cultura e Criança. São Paulo: Papirus, 1994.

AZEVEDO, N. C. S. "Programa Cidadescola" no 10 ano do ensino fundamental em uma escola de Presidente Prudente: entre a ludicidade e a sala de aula. 2012. 213 f. Dissertação (Mestrado em Educação) - Universidade Estadual Paulista UNESP, Presidente Prudente, 2012.

AZEVEDO, N. C. S. Culturas lúdicas infantis na escola: entre a proibição e a criação. 2016. 249 f. Tese (Doutorado em Educação) - Universidade Estadual Paulista - UNESP, Presidente Prudente, 2016.

AZEVEDO, N. C. S.; BETTI, M. Pesquisa etnográfica com crianças: caminhos teórico-metodológicos. Nuances: estudos sobre Educação, Presidente Prudente, v. 5, n. 2, p. 291-310, mai./ ago. 2014.

BRAYNER, F. Da criança-cidadã ao fim da infância. Educação \& Sociedade, Campinas, n. 6, p. 197211, out. 2001.

CHAMBOREDON, J. C.; PRÉVOT, J. O Ofício de Criança. In: S. GRÁCIO, S.; STOER, S. Sociologia da Educação II. Antologia. A Construção Social das Práticas Educativas. Lisboa: Livros Horizonte, 1982, p. $51-77$.

CORDEIRO, S. S.; COELHO, M. G. P. Descortinando o conceito de infância na história: do passado à contemporaneidade. 2007. Disponível em: $<$ http://www2.faced.ufu.br/colubhe06/anais/arq uivos/76SandroSilvaCordeiro MariaPintoCoelho. pdf>. Acesso em: 07 set. 2016.

CORSARO, W. Sociologia da infância. Porto Alegre: Artmed, 2011.

DELGADO, A. C. C.; MÜLLER, F. Abordagens etnográficas nas pesquisas com crianças. In: CRUZ, S. H. V. (Org). A criança fala: a escuta de crianças em pesquisas. São Paulo: Cortez, 2008. p. 141-157.

DEL PRIORE, M. História das crianças no Brasil: apresentação. In: DEL PRIORE, M. (Org.). História das crianças no Brasil. São Paulo: Contexto, 2010, p. 6-18.

DEWEY, J. John Dewey. Pedagogia, história, filosofia, sociologia, magistério. São Paulo: Ícone, 1999.

DURKHEIM, E. Sociologia, educação e moral. Portugal: Rés, 1984.

FARIA, A. L. G. Políticas de regulação, Pesquisa e Pedagogia na Educação Infantil, Primeira etapa da Educação Básica. Educação e Sociedade, vol.26, n.92, p. 1.013-1.038, Especial - Out. 2005.

FERNANDES, F. Folclore e mudança social na cidade de São Paulo. São Paulo: Martins Fontes, 2004.

FERREIRA, M. M. M. "A gente aqui o que gosta mais é de brincar com os outros meninos!": as crianças como atores sociais e a (re) organização social do grupo de pares no cotidiano de um Jardim de Infância. 2002. 646 f. Tese (Doutorado em Ciências da Educação) - Faculdade de Psicologia e Ciências da Educação, Universidade do Porto, Porto, 2002.

FERREIRA. M. M. "Branco demasiado" ou... reflexões epistemológicas, metodológicas e éticas acerca da pesquisa com crianças. In: SARMENTO, M. J.; GOUVEA, M. C. S. (Orgs.). Estudos da infância: educação e práticas sociais. Petrópolis: Vozes, 2009. p. 143-162.

FERREIRA, M.; SARMENTO, M. J. Subjectividade e bem-estar das crianças: (in)visibilidade e voz. Revista Eletrônica de Educação, São Carlos, v.2, n.2, p. 60-91, nov. 2008.

FREIRE, I. Cidadania da criança: escola e sociedade como palcos de participação. EDUSER: revista de educação, Bragança-PT, v. 3, n. 2, p. 17-26, 2011.

GIRARDELLO, G. Produção cultural infantil diante da tela: da TV à internet. Teias, Rio de Janeiro, v. 6, n. 11-12, p. 1-12, jan./dez. 2005.

JAMES, A.; PROUT, A. O novo paradigma da sociologia da infância? : proveniência, promessas e problemas. In: JAMES, A.; PROUT, A. Construção e reconstrução da infância. Londres: Falmer, 1997. 
KUHLMANN JÚNIOR, M. Infância e educação infantil: uma abordagem histórica. Porto Alegre: Mediação, 1998.

KUHLMANN JÚNIOR, M. Educando a infância brasileira. In: LOPES, E.M.T.; FARIA FILHO, L.M.; VEIGA, C.G. (orgs.). 500 anos de educação no Brasil. Belo Horizonte: Autêntica, p. 469-496.

MÜLLER, F.; CARVALHO, A. M. A. Encontros e diálogos: notas introdutórias. In: MÜLLER, F.; CARVALHO, A. M. A. (Orgs). Teoria e prática na pesquisa com crianças: diálogos com Willian Corsaro. São Paulo, Cortez, 2009. p. 21-28.

NEVES, V. A. F. Tensões contemporâneas no processo de passagem da infância para o ensino fundamental: um estudo de caso. 2010. 271f. Tese (Doutorado em Educação) - Universidade Federal de Minas Gerais, Belo Horizonte, 2010.

POYER, V. Sociologia da educação: livro didático: design instrucional. Palhoça: Unisul Virtual, 2007.

RAMOS, F. P. A história trágico-marítima das crianças nas embarcações portuguesas do século XVI. In: DEL PRIORE, M. (Org.). História das crianças no Brasil. São Paulo: Contexto, 2010. p. 19-54.

SANTOS, B. S. Uma cartografia simbólica das representações sociais: prolegómenos a uma concepção pós-moderna do direito. Revista Crítica das Ciências Sociais, Lisboa-PT, n. 24, p. 139-172, mar. 1988.

SARAMAGO, S. S. S. Metodologia de pesquisa empírica com crianças. Sociologia, Problemas e Práticas, Lisboa-PT, n. 35, p. 9-29, 2001.

SARMENTO, M. J. Infância, exclusão social e educação como utopia realizável. Educação \& Sociedade, Campinas, ano XXIII, n.78, p. 265-283, abr. 2002.

SARMENTO, M. J. As culturas da infância nas encruzilhadas da segunda modernidade. In: SARMENTO, M. J.; P.; CERISARA, A. B. (Orgs.). Crianças e miúdos: perspectivas sociológicas da infância e educação. Porto: Asa Editores, 2004. p. 9-34.
SARMENTO, M. J. Conhecer a infância: os desenhos das crianças como produções simbólicas. In: FILHO, A. J. M.; PRADO, P. D. (Orgs.). Das pesquisas com crianças à complexidade da infância. Campinas, Autores Associados, 2011. p. 27-60.

SARMENTO, M. J. Infância contemporânea e educação infantil: uma perspectiva a partir dos direitos da criança. In: SALMAZE, M. A.; ALMEIDA, $O$. A. Primeira infância no século XXI: direito das crianças de viver, brincar, explorar e conhecer o mundo. Campo Grande: Oeste, 2013, p. 131 148.

SARMENTO, M. J.; PINTO, M. "As crianças e a infância: definindo conceitos, delimitando o campo". In: PINTO, M.; SARMENTO, M. J. (Orgs.). As Crianças: contextos e identidades. Braga: Centro de Estudos da Criança da Universidade do Minho, 1997, p. 7-30.

SILVA, C. V. M.; FRANCISCHINI, R. O surgimento da Educação Infantil nas histórias das políticas públicas para a criança no Brasil. Práxis Educacional, Vitória da Conquista, v. 8, n. 12, p. 257-276, jan./jun. 2012.

SIROTA, R. Emergência de uma sociologia da infância: evolução do objeto e do olhar. Cadernos de Pesquisa, São Paulo, n. 112, p. 7-31, mar. 2001.

TOMÁS, C. Paradigmas, imagens e concepções da infância em sociedades mediatizadas. Media \& Jornalismo, Lisboa-PT, v. 11, p. 119-134, 2007.

TOMÁS, C.; SOARES, N. F. Infância, protagonismo e cidadania: contributos para uma análise sociológica da cidadania da infância. Fórum Sociológico, Lisboa-PT, n.11/12, p. 349-361, 2004.

Recebido para publicação em: 04/05/2017

Revisado em: 06/11/2017

Aceito em: 15/11/2017 